\title{
CREB3L1 wt Allele
}

National Cancer Institute

\section{Source}

National Cancer Institute. CREB3L1 wt Allele. NCI Thesaurus. Code C95478.

Human CREB3L1 wild-type allele is located in the vicinity of $11 \mathrm{p} 11.2$ and is approximately $44 \mathrm{~kb}$ in length. This allele, which encodes cyclic AMP-responsive element-binding protein 3 -like protein 1 , is involved in the modulation of transcription. 